\title{
USE OF ENZYMATIC BIOSENSORS AS QUALITY INDICES: A SYNOPSIS OF PRESENT AND FUTURE TRENDS IN THE FOOD INDUSTRY
}

\author{
Liliana Serna Cock ${ }^{1 *}$, Ana María Zetty Arenas', and Alfredo Ayala Aponte ${ }^{2}$
}

\begin{abstract}
Biosensors are an important alternative in the food industry to ensure the quality and safety of products and process controls with effective, fast and economical methods. Their technology is based on a specific biological recognition element in combination with a transducer for signal processing. The use of enzymatic biosensor technology in food processing, quality control and on-line processes is promising compared to conventional analytical techniques, as it offers great advantages due to size, cost, specificity, fast response, precision and sensitivity. This article reviews the development and use of some enzyme biosensors in the food industry, describes the most important application areas and analyzes the current situation and future possibilities. In conclusion, enzymatic biosensors are a tool with broad application in the development of quality systems, risk analysis and critical control points, and the extent of their use in the food industry is still largely limited by the short lifetime of biosensors, in response to which the use of thermophilic enzymes has been proposed.
\end{abstract}

Key words: biosensors, enzymes, analysis in food, safety, quality, control processes.

\section{INTRODUCTION}

In recent decades increased knowledge about the biological capacity of enzymes has made it possible to create a new generation of products and processes. Among these products are notably biosensors, which represent a powerful alternative to conventional analytical technique (Velasco-García and Mottram, 2003). This technology has advanced considerably in recent years, basically because of the creation of devices applied in the area of biomedicine. These advanced technologies have been gradually transferred horizontally to other sectors, such as the environment and the agro-food industry.

A biosensor is defined as a compact device for analysis that incorporates a biological or biomimetic recognition element (nucleic acid, enzyme, anti-body, receptor, tissue, cell) associated with a transduction system that allows for processing the signal produced by the interaction between the recognition element and the analyte. The principle of detection of a biosensor is based on the specific interaction between the analyte of interest and the recognition element. As a result of this specific interaction, changes are produced

${ }^{1}$ Universidad Nacional de Colombia sede Palmira, Facultad de Ingeniería y Administración, Carrera 32 Chapinero, Vía Candelaria, Palmira, Colombia.

"Corresponding author (lsernac@palmira.unal.edu.co).

${ }^{2}$ Universidad del Valle, Facultad de Ingeniería, Edificio 338, Espacio 2016, Ciudad Universitaria, Cali, Colombia.

Received: 11 December 2007.

Accepted: 05 May 2008. in one or several physical-chemical properties (pH, electron transference, heat transference, change of potential or mass, variation of optical properties, etc.). These changes are detected and can be measured by a transductor (VelascoGarcía and Mottram, 2003). This system transforms the response of the recognition element into an electronic signal indicative of the presence of the analyte under study or proportional to its concentration in the sample.

Biosensors currently represent powerful tools for analysis with numerous applications in the agro-food industry, mainly in biotechnological instruments (Mello and Kubota, 2002). The most important characteristics of these devices to be competitive with other technologies in the agro-food industry are their specificity, high sensitivity, short response time, their capacity to be incorporated into integrated systems, the facility to automate them, their capacity to work in real time, their versatility and low production cost (Rasooly, 2001; Mello and Kubota, 2002; Velasco-García and Mottram, 2003).

In recent years, the number of scientific investigations and reviews on biosensors has been very high, which reflects the considerable interest in the theme. Ironically, there is a lag between the high level of scientific and technological development and the limited use of these devices in the agro-food sector (Velasco-García and Mottram, 2003) basically because of structural characteristics of the sector, such as legislation, methodological inertia, absorption capacity and environmental factors. The development of the diverse technologies involved in the design and construction of biosensors has allowed in recent years for 
resolving technical difficulties and personalized design of biosensors that, from the technical point of view, cover practically all needs.

The development of biosensors is described in numerous works, the majority in the areas of clinical, environmental, agricultural and biotechnological applications (Tothill, 2001). Their use in the food sector is convenient to ensure the quality and safety of foods (Luong et al., 1991). The potential uses of biosensors in agriculture and food transformation are numerous and each application has its own requirements in terms of the concentration of analyte to be measured, required output precision, the necessary volume of the sample, time required for the analysis, time required to prepare the biosensor or to reuse it and cleanliness requirements of the system (Velasco-García and Mottram, 2003).

Biosensors have been adapted to detect or measure analytes in "on-line" systems, that is, simultaneous with food processing (Rasooly, 2001). Hazard Analysis and Critical Control Point (HACCP) is generally regarded as the most effective system to ensure food safety. It is highly useful in verifying that processes are under control. The high sensitivity of enzymatic biosensors allows for the detection of microorganisms such as Escherichia coli, Salmonella sp., Staphylococcus aureus, pesticides and herbicides, among others, in hours and/or minutes (Fitzpatrick et al., 2000; Killard and Smyth, 2000).

Innovation and development in the food industry are guided by the central principles: food safety and quality (Mello and Kubota, 2002; Ferreira et al., 2003). The increasing complexity of the food chain requires, among other things, the development of effective traceability systems that guarantee the solidity of all the links. In both cases, the priority is to develop and install control systems such as biosensors that involve molecular methods of detection, analysis and diagnosis that are rapid, highly sensitive and automated tracing for a wide range of agents that threaten food safety.

Given the applicability of biosensors, this article reviews the development and use of some enzymatic biosensors in the food industry, describing the three main areas of application: food safety, food quality and process control, the current situation and future possibilities. As well, there is a brief commentary on the aspects of catalytic biosensors and their classification according to the type of interaction established between the recognition element and the analyte.

\section{Enzymatic biosensors}

A catalytic biosensor can be described as a compact analytic device that incorporates a biological sensing element, closely connected to or integrated with a transductor system (Velasco-García and Mottram, 2003). Biological sensors include enzymes or multi-enzymatic mediums, cellular organelles, complete cells or animal or vegetal tissue (Davis et al., 1995; Mello and Kubota, 2002; Wilson and Gifford, 2005), which are used to detect the presence of any of the substrates that participate in the reaction by detecting the disappearance of a known substrate distinct from the substrate being sought, or by the appearance of a known product; biological sensors are not consumed and can be reused (Gajovic et al., 2000; Wilson and Gifford, 2005).

In enzymatic biosensors a reaction occurs catalyzed by an enzyme in which the union of the substrate is produced in a concrete region of the enzyme termed the active center, which upon forming the products is recovered and can begin a new reaction cycle. The use of enzymes as biological recognition elements was very popular in the first generation of development of biosensors owing to their commercial availability or the facility for isolation and purification of diverse sources (Luong et al., 2008). Subsequently, other advantages were found in using enzymes in recognition biosensors, such as rapid response, high selectivity, the possibility of regeneration and the simplicity involved in constructing the devices (Hall, 2002). In numerous cases multi-enzymatic chains are employed, where the enzyme that generally recognizes the analyte does not act directly on it, but rather interacts with some product derived from it. This technique is often used, for example, with some sugars, where enzymes that are used react with the products of hydrolysis of the same. Among the enzymes that are commercially available, the most often used in biosensors are oxidoreductase, notably among which are glucose oxidase, horseradish peroxidase and alkaline phosphatase (Rogers and Mascini, 1998; Laschi et al., 2000), because they are very stable catalyzing reactions of oxide reduction (Mello and Kubota, 2002).

More than 2000 articles on enzyme-based biosensors were found in the literature and this is because of the need to examine blood glucose (Tothill, 2001; D’Orazio, 2003) and the feasibility of construction of the same. In the majority of the applications, the detection limits are satisfactory or excessive, but the stability of the enzymes and the capacity to maintain enzymatic activity over a long period of time continues to be problematic, which is generally resolved by immobilizing the enzymes (Tothill, 2001; D’Orazio, 2003). Immobilized enzymes offer advantages for application in different types of industrial processes and are adaptable to new engineering designs (Krajewska, 2004), for which it is important to increase the affinity of the enzyme to the substrate, reduce inhibition, increase the optimal $\mathrm{pH}$ interval and reduce possible microbial contamination (Arroyo, 1998). Basically, in enzymatic biosensors the enzymes are immobilized in a potentiometric, amperometric, optometric, calorimetric or piezoelectric transductor (Davis et al., 1995). 
In some cases electro-active interference caused by endogenous compounds in the sample for analysis becomes significant and needs to be eliminated. Currently, glucose oxidase continues to be the most stable and specific enzyme that can be easily obtained in large quantities (Luong et al., 2008).

On the other hand, there are enzymes that cannot be used because they are not sufficiently stable or because their purification is difficult or too costly, because of which cells from bacteria, fungus, protozoa and higher organisms are being used (Mello and Kubota, 2002). Instead of being purified, these cells are used as biological recognition elements, taking advantage of their diverse multi-cellular enzymatic systems that possess the capacity to metabolize different organic compounds, generating distinct products such as ammonia, carbon dioxide, acids, sugars, vitamins and nitrogenated compounds, among others, which can be detected in the biosensors, and in turn can be used to detect compounds that inhibit microbial respiration as toxic and contaminating substances (D’Souza, 2001). As well, the cells offer the facility to be modified genetically to improve their activity or to produce specific enzymes that do not normally appear.

One of the most important limitations in the use of complete cells is the diffusion of substrates and products by means of the cellular membrane, with which a slower response is obtained in comparison to purified enzyme biosensors, and with less specificity owing to reactions catalyzed by other enzymes present in the cell (D'Souza, 2001). These limitations can be reduced through the permeabilization of the cellular membrane by means of enzymatic processes with lysozyme, papain, chemical processes with detergents and physical processes with freezing and thawing (Mello and Kubota, 2002). These processes permit an increase in porosity of the membrane, allowing for better incorporation of the analyte and impede the escape of the intercellular macromolecular compounds, while the enzymes at the same time allow the co-factors that intervene in the catalytic reactions to leave to the exterior of the cell. Consequently, such treatments provoke cellular inviability, which limits their use to applications that do not require cellular regeneration of co-factors or metabolic respiration, as is the case of glucose oxidase, ß-galactosidase, amino acid oxidase and invertase (D’Souza, 2001).

Cells can be immobilized in membranes of cellulose acetate, or be trapped in a matrix, such as agar gel (Patel, 2002; Tatsumi et al., 2006; Setti et al., 2007) in a simpler and more economical way than enzymatic immobilization.

Other systems of catalytic biosensors instead of using complete cells or isolated multi-enzymatic include subcellular organelles or tissue, that contain more specific complete enzymatic systems, as is the case of thylakoids, complete chloroplasts or mitochondria, which are doublemembrane organelles that have enzymatic systems related to obtaining energy. Such organelles are used in the detection of toxic agents such as pesticides, heavy metals or detergents that can inhibit enzymatic systems (D'Souza, 2001). In the same manner, there are determined tissues that according to their physiological function in the organism produce specific enzymes or enzymatic systems, such as leaves, roots, fruits or seeds, in sliced or in homogenized form; such tissue are often associated with electrochemical transductors (Li et al., 2002; Wilson and Gifford, 2005; Mei et al., 2007). For example, for the detection of phenol impregnated in salmon, salmon tissue is used in an electrochemical biosensor of carbon and tyrosinase mixed with electropolymerized pyrrole (Tingry et al., 2006); slices of potato are used for the determination of mono and polyphenoles (Solanum tuberosum L.) because of their high content of polyphenol oxidase enzymes, together with oxygen electrodes (D’Souza, 2001; Kulys and Vidziunaite, 2003); for the determination of alcohol, homogenized fungus Agaricus bisporus is used (Akyilmaz and Dinckaya, 2000; Kulys and Vidziunaite, 2003); for the determination of diamines like putrescine and cadaverine, tissue is used from chemiluminescent plants, based on the enzymatic conversion that takes place in the column of tissue of the plants to produce hydrogen peroxide (Mei et al., 2007), among many others examples.

The application of more than one sensor channel for one or more species in a unit using enzyme-electrode type amperometric sensors has led to the development of several multi-sensors based on principles of amperometric detection (Silber et al., 1994; Miertus et al., 1998). The use of electro-chemical transductors of various channels allows for the construction of biosensors that can simultaneously analyze three or more species and in this manner optimize selectiveness and reliability in comparison to sensors with only one substrate (Glazier et al., 1988).

\section{Potential applications of enzymatic biosensors in the agro-food industry}

Applications in food safety. The concept of food safety involves ensuring the production and marketing of harmless food, with this, ensure the health of the consumer. The quantity and types of food additives incorporated into food products are regulated by the legislation of each country, the detection and quantification of which are important to prevent fraud and malpractice by manufacturers, allergies and other adverse effects to determined groups of the population (Zinedine et al., 2007). Because of this, special attention has been given to studying the way to detect the presence of contaminants, such as residues of pesticides, fertilizers, 
heavy metals and organic compounds, given that the majority of these have a high level of toxicity. Based on this need biosensors are used to detect xenobiotic substances, substances external to the food product such as additives and pesticides and components of the food itself like toxines of diverse origins (Xavier et al, 2000; Patel, 2002). The traditional methods to identify food contaminants include physiochemical, serological and biological tests, however many of these require large quantities of prepared samples, analysis time and lack sufficient sensitivity and selectivity.

The development of catalytic biosensors in food additive analysis generally employs enzymes as recognition systems. This development is described in several investigations, among these notably are analysis of aspartame with carboxyl esterase, alcohol oxidase, caboxypeptidase, L-aspartase, peptidase, aspartate aminotransferase, glutamate oxidase and $\alpha$-chymotrypsin (Odaci et al., 2004); analysis of sorbitol with sorbitol dehydrogenase and nicotinamide adenine dinucleotide (NAD+) (Saidman et al., 2000); analysis of benzoic acid with tyrosine (Morales et al., 2002) and analysis of sulphites with sulphite oxidase; all developed with a system of amperometric transduction. In some cases interference reactions have been observed that reduce the efficacy of these devices, as occurs with biosensors used to detect sorbitol which also interact with another artificial edulcorant, xylitol; and with devices designed for the determination of benzoic acid by the presence of other antioxidants such as butyl hydroxyanisole (BHA) and propyl gallate (Patel, 2002). Table 1 presents the main biosensors used in the detection of these types of compounds in food and water; among these are devices based on the inhibition of enzymatic activities that incorporate enzymes such as cholinesterases (acetyl and/or butyrylcholinesterases), tyrosinase or alkaline phosphatase; and units in which reactions are catalyzed that affect the analyte of interest, which include hydrolases, reductases, etc. (Nunes et al., 1998; Bachmann et al., 2000; Panfili et al., 2000).

The different pesticides used in food production can accumulate in the fatty tissue of animals, while the excessive use of fertilizers contaminates ground water with nitrates, nitrites and phosphates (Cosnier et al., 1998; Moretto et al., 1998). For the detection of herbicides such as phenyl urea and triazines, which inhibit photosynthesis, biosensors have been designed with membrane receptors of thylakoid and chloroplasts, photosystems and reaction centers; or complete cells such unicellular alga and fenilureas and triazines, for which mainly amperometric and optical transductors have been employed (Patel, 2002).
There are also other substances potentially toxic for humans with a major impact on the environment that can reach the food chain accidentally, such as contaminating residues present in water and soil, among these byproducts from diverse industrial processes (dioxins), used as dielectric or hydraulic fluid agents (polychlorinated biphenyls or PCBs) or generated in the burning of fossil fuels or wood (polycyclic aromatic hydrocarbons or PAHs), benzene, toluene and xylene (named BETX) and derived phenolics; immunosensors, enzymatic biosensors and biosensors with complete cells are used for the detection of these organic compounds (Hedenmo et al., 1997; Patel, 2002). Likewise, devices have been designed to determine the levels of heavy metals such as arsenic, cadmium, mercury, lead, among others, in samples of water and soil, which incorporate genetically modified microorganisms and enzymes such as urease, cholinesterase, glucose oxidase, alkaline phosphatase, ascorbate oxidase and peroxidase (Tsai et al., 2003), the transduction systems in these devices are notably electrochemical and optical, as indicated in Table 1.

On the other hand, foods can naturally present antinutritional compounds that can generate disorders in the consumer, given that they hinder absorption and metabolize distinct nutrients causing a deficiency of the same. Table 2 presents some examples of biosensors used in the detection of anti-nutrients.

Applications in food quality. The term food quality is related to nutritional value, acceptability and safety. The latter was analyzed in the previous section and the others are evaluated in function of parameters such as freshness, appearance, flavor, texture and chemical (Vadiuambal and Jayas, 2007). The composition of the foods allows for characterization and verification if the food contains elements to enrich the food such as vitamins and/or minerals. To evaluate food composition distinct biosensors have been developed, which are described in Table 3.

Various food labeling regulations recognize the importance of determining freshness, establishing guidelines for the use of the term "fresh" in relation to food (FSA, 2004). One way to determine freshness is through evaluation of the composition of products such as meats, fish, fruits and vegetables, given that during periods of storage compounds can by synthesized that produce abnormal odors and flavors and are prejudicial to the health of the consumer. Table 4 lists the biosensors developed to evaluate the freshness and useful life of foods.

Some of the most important problems that affect food freshness, and with it food quality, are exposure time in an inadequate environment, incorrect design of the food packaging, inadequate management of temperatures 
Table 1. Most important biosensors used in the detection of pesticides, fertilizers and other pollutants.

\begin{tabular}{|c|c|c|c|c|}
\hline Analyte & $\begin{array}{c}\text { Type of } \\
\text { interaction }\end{array}$ & $\begin{array}{l}\text { Recognition } \\
\text { biocatalyzer }\end{array}$ & $\begin{array}{c}\text { Transduction } \\
\text { system }\end{array}$ & References \\
\hline \multicolumn{5}{|c|}{ Pesticides } \\
\hline Parathion & Biocatalytic & Parathion hydrolase & Amperometric & $\begin{array}{l}\text { Velasco-García y } \\
\text { Mottram, 2003; } \\
\text { Parellada et al., } 1998\end{array}$ \\
\hline Propoxur and carbaryl & Biocatalytic & Acetyl cholinesterase & Fiber optic & $\begin{array}{l}\text { Nunes et al., 1998; } \\
\text { Xavier et al., } 2000\end{array}$ \\
\hline Diazinon and dichlorvos & Biocatalytic & Tyrosinase & Amperometric & $\begin{array}{l}\text { Pérez Pita et al., 1997; } \\
\text { Mello y Kubota, } 2002\end{array}$ \\
\hline Paraoxon & Biocatalytic & Alkaline phosphatase & Optical & $\begin{array}{l}\text { Cosnier et al., 1998; } \\
\text { Mello and Kubota, } \\
\text { 2002; Patel, } 2002\end{array}$ \\
\hline
\end{tabular}

\section{Fertilizers}

\begin{tabular}{|c|c|c|c|c|}
\hline Nitrate & Biocatalytic & Nitrate reductase & Amperometric & Moretto et al., 1998 \\
\hline Nitrite & Biocatalytic & Nitrite reductase & Optical & Moretto et al., 1998 \\
\hline Phosphate & Biocatalytic & $\begin{array}{l}\text { Polyphenol oxidase and } \\
\text { alkaline phosphatase, } \\
\text { phosphorylase A, } \\
\text { phosphoglucomutase and } \\
\text { glucose-6-phosphate } \\
\text { dehydrogenase }\end{array}$ & Amperometric & Cosnier et al., 1998 \\
\hline
\end{tabular}

\section{Heavy metals}

\begin{tabular}{|c|c|c|c|c|}
\hline Copper and mercury & Biocatalytic & Spirulina subsalsa & Amperometric & $\begin{array}{l}\text { Tsai, 2003; Velasco- } \\
\text { García and Mottram, } 2003\end{array}$ \\
\hline Copper & Biocatalytic & $\begin{array}{l}\text { Recombinant Saccharomyces } \\
\text { cerevisiae }\end{array}$ & Amperometric & $\begin{array}{l}\text { Tsai, 2003; Velasco- } \\
\text { García and Mottram, } 2003\end{array}$ \\
\hline Cadmium and lead & Biocatalytic & $\begin{array}{l}\text { Staphylococcus aureus or } \\
\text { Recombinant Bacillus subtilis }\end{array}$ & Optical & $\begin{array}{l}\text { Tsai, 2003; Velasco- } \\
\text { García and Mottram, } 2003\end{array}$ \\
\hline $\begin{array}{l}\text { Arsenic, cadmium and } \\
\text { bismuth }\end{array}$ & Biocatalytic & Cholinesterase & Electrochemical & $\begin{array}{l}\text { Tsai, 2003; Velasco- } \\
\text { García and Mottram, } 2003\end{array}$ \\
\hline $\begin{array}{l}\text { Cadmium, copper, } \\
\text { chrome, nickel, zinc }\end{array}$ & Biocatalytic & Ureasa & Optical & $\begin{array}{l}\text { Tsai, 2003; Velasco- } \\
\text { García and Mottram, } 2003\end{array}$ \\
\hline Copper and mercury & Biocatalytic & Glucose oxidase & Amperometric & $\begin{array}{l}\text { Tsai, 2003; Velasco- } \\
\text { García and Mottram, } 2003\end{array}$ \\
\hline
\end{tabular}

and the level of oxygen during the handling of fruit and vegetables in modified atmospheres, among many others. Because of this, experimental use has been made of commercial biosensors that use immobilized enzymes like alcohol oxidase and alcohol peroxidase and a chromogene, in which alcohol oxidase catalyzes the oxidation of ethanol in acetaldehyde and $\mathrm{H}_{2} \mathrm{O}_{2}$ in the presence of $\mathrm{O}_{2}$, and the peroxidase catalyzes the oxidation of the chromogene, causing a change in color. Smyth et al. (1999), measuring with biosensors, ethanol accumulation in lettuce (Lactuca sativa L.), cauliflower (Brassica oleracea var. botrytis), broccoli (Brassica oleracea var. italica) and cabbage (Brassica oleracea var. capitata) lightly processed and packed in a modified atmosphere, detected lesions due to low concentration of $\mathrm{O}_{2}$ and obtained a response from the biosensor that was very similar to that obtained by gas chromatography, which is costly and requires technical experts. This biosensor can also be used monitor ethanol formation during apple storage in a controlled atmosphere, the development of putrefaction in tubercles like potatoes or for any other application where ethanol accumulation can be associated with quality loss. Likewise, research has 
Table 2. Some of the most commonly used biosensors in antinutrient detection.

\begin{tabular}{lcccc}
\hline Analyte & $\begin{array}{c}\text { Type of } \\
\text { interaction }\end{array}$ & $\begin{array}{c}\text { Recognition } \\
\text { system }\end{array}$ & $\begin{array}{c}\text { Transduction } \\
\text { system }\end{array}$ & References \\
\hline Oxalate (spinaches, tea, strawberries) & \multicolumn{3}{c}{ Antinutrients } & \\
Amygdalin (bitter almonds) & Biocatalytic & $\begin{array}{l}\text { Oxalate oxidase } \\
\text { B-glucosidase }\end{array}$ & $\begin{array}{l}\text { Amperometric } \\
\text { Amperometric }\end{array}$ & Milardovic et al., 2000 \\
& & & $\begin{array}{l}\text { Potentiometric } \\
\text { Glucoalcaloides }\end{array}$ & Ohashi and Karube, 1993 \\
\hline
\end{tabular}

been conducted that analyzes the content of some organic acids and sugars as indicators of fruit and vegetable maturity (Ángeles and Cañizares, 2004).

There are multiple compounds that give rise to disagreeable flavors and aromas that can be detected with biosensors, as in the case of 2,4,6-tricloroanisole in wine (Moore et al., 2003), which is related to wine bottle corks, whose presence causes significant losses to the wine industry. In other cases, the level of freshness of fish has been detected through a hydrogen peroxide electrode based on the xanthine oxidase enzyme (Volpe and Mascini, 1996). Biosensors can also detect indicators of processes, such as lactulose, disaccharide, which is formed in the thermal treatment of milk allows for distinguishing between milk that has been submitted to a UHT treatment (ultra high temperature) and milk sterilized in the container.

Applications in process control. Currently, thanks to biosensor technology it is possible to determine and quantify on-line diverse compounds of importance in process control, such as sugars, alcohols, and amino acids, among others.

Sugars are limiting factors in fermentative processes given that low concentrations reduce the productivity of the bioreactor. Because of this, numerous investigations have been undertaken, among which notably are those on the use of amperometric biosensors to analyze glucose with glucose oxidase in fruit juices (Ángeles and Cañizares, 2004); lactose with ß-galactosidase and glucose oxidase; and lactulose with ß-galactosidase and fructose dehydrogenase, which implies an excessive thermal treatment of milk during pasteurization (Campás et al., 2002). In relation to alcohols and principally ethanol, enzymatic reactions are inhibited when alcohol content exceeds $14 \%$; analysis has been advanced mainly with the alcohol dehydrogenase enzyme Gluconobacter oxydans with amperometric biosensors; likewise, with fermentation, the proportion of glycerol should be maintained at 1:10 in relation to total alcohol, the analysis of glycerol has been developed with glycerokinase and glycerol-3-phosphate oxidase in amperometric biosensors to monitor fermentative processes (Niculescu et al., 2003). On the other hand, aminoacids like lysine, obtained by fermentation and employed as animal feed supplements, has been controlled by the lysine oxidase enzyme. Similarly, lactic acid used to control acidity and the formation of crusts on cheese, have been examined with lactate oxidase in amperometric biosensors. These biosensors can be integrated into the system of Hazard Analysis and Critical Control Points (HACCP) to verify that processes are being carried out correctly.

Despite the broad applicability of biosensors, the use of the technology in the control of processes is limited for several reasons: the short life of enzymatic biosensors, the need to calibrate them with certain frequency, the lack of reliable response to different concentrations or with variable conditions in the medium, among others (Ferreira et al., 2003). The prototype tests in real samples have critical stages such as immobilization of the biocomponent during the construction of the device and preparation of the sample for analysis. Biosensors require mild temperature and $\mathrm{pH}$ conditions to keep the biological element active (Gibson, 1999; Wilson and Gifford, 2005). Consequently, in some cases a previous treatment of the sample is recommended to eliminate interfering species such as ascorbic acid, tyrosine and others. Procedures are conducted that include neutralization, dilution or extraction when the food is acidic or hydrophobic. The correction methods to reduce the duration of food analysis include acidic or alkaline hydrolysis, microwave digestion, extraction of supercritical fluids, evaporation and filtration (Deng and Dong, 1996; Marconi et al., 1996; Kotsira and Clonis, 1998; Panfili et al., 2000). Likewise, specific sensors have been developed for the determination of glucose, lactate, glutamate, pyruvate, choline and acetylcholine through monitoring of nitric oxide, $\mathrm{Na}^{+}, \mathrm{K}^{+}, \mathrm{Ca}^{2+}$, and dopamine (Zhang and Wilson, 1998; Wilson and Gifford, 2005).

\section{CONCLUSIONS}

The food industry is benefitting from major advances in the development of enzymatic biosensors with different transduction systems that can be applied in the areas of food safety, quality and process control; studies are focused mainly on determining composition, contamination of primary materials and processed foods. 
Table 3. Most important biosensors applied to evaluate food quality.

\begin{tabular}{|c|c|c|c|c|}
\hline Analyte & Matrix & $\begin{array}{l}\text { Recognition } \\
\text { enzyme }\end{array}$ & $\begin{array}{c}\text { Transduction } \\
\text { system }\end{array}$ & References \\
\hline Glucose & $\begin{array}{l}\text { Grape juice, wine, juice, } \\
\text { honey, milk and yogurt }\end{array}$ & Glucose oxidase & Amperometric & $\begin{array}{l}\text { Centonze et al., 1997; } \\
\text { Ángeles y Cañizares, } 2004\end{array}$ \\
\hline Fructose & $\begin{array}{l}\text { Juice, honey, milk, gelatin } \\
\text { and artificial edulcorants }\end{array}$ & $\begin{array}{l}\text { Fructose dehydrogenase, } \\
\text { D-fructose 5- } \\
\text { dehydrogenase }\end{array}$ & Amperometric & $\begin{array}{l}\text { Bassi et al., 1998; } \\
\text { Palmisano et al., } 2000\end{array}$ \\
\hline Lactose & Milk & ß-Galactosidase & Amperometric & $\begin{array}{l}\text { Marconi, 1996; Palmisano } \\
\text { et al., } 2000\end{array}$ \\
\hline Lactate & Cider and wine & $\begin{array}{l}\text { Transaminase and L- } \\
\text { lactate dehydrogenase }\end{array}$ & Amperometric & $\begin{array}{l}\text { Silber et al., 1994; } \\
\text { Ramanathan et al., } 2001\end{array}$ \\
\hline Lactulose & Milk & $\begin{array}{l}\text { Fructose dehydrogenase } \\
\text { and ß-galactosidase }\end{array}$ & Amperometric & Sekine and Hall, 1998 \\
\hline $\begin{array}{l}\text { L-amino } \\
\text { acids }\end{array}$ & Milk and fruit juices & D-amino acid oxidase & Amperometric & Sarkar et al., 1999 \\
\hline L-glutamate & $\begin{array}{l}\text { Soya sauce and } \\
\text { condiments }\end{array}$ & L-glutamate oxidase & Amperometric & $\begin{array}{l}\text { Matsumoto et al., 1998; } \\
\text { Kwong et al., } 2000\end{array}$ \\
\hline L-lysine & $\begin{array}{l}\text { Milk, pasta and } \\
\text { fermentation samples }\end{array}$ & Lysine oxidase & Amperometric & $\begin{array}{l}\text { Kelly et al., 2000; } \\
\text { Olschewski et al, } 2000\end{array}$ \\
\hline L-malate & Wine, cider and juices & $\begin{array}{l}\text { Dehydrogenated malate, } \\
\text { others }\end{array}$ & Amperometric & Miertus et al., 1998 \\
\hline Ethanol & $\begin{array}{l}\text { Beer, wine and other } \\
\text { alcoholic drinks }\end{array}$ & $\begin{array}{l}\text { Alcohol oxidase, alcohol } \\
\text { dehydrogenase, } \mathrm{NaDH} \\
\text { oxidase }\end{array}$ & Amperometric & $\begin{array}{l}\text { Katrlık, } 1998 \text {; Miertus et } \\
\text { al., } 1998\end{array}$ \\
\hline Glycerol & Wine & $\begin{array}{l}\text { Glycerophosphate } \\
\text { oxidase and glycerol } \\
\text { kinase }\end{array}$ & Amperometric & Niculescua et al., 2003 \\
\hline Catechol & Beer & Polyphenol oxidase & Amperometric & Eggins et al., 1997 \\
\hline Cholesterol & Butter, lard and egg & $\begin{array}{l}\text { Cholesterol oxidase and } \\
\text { peroxidase }\end{array}$ & Amperometric & $\begin{array}{l}\text { Akyilmaz and Dinckaya, } \\
2000 .\end{array}$ \\
\hline Citric acid & Juice and athletic drinks & Citrate lyase & Amperometric & Prodromidis et al., 1997 \\
\hline Lecithin & $\begin{array}{l}\text { Egg yolk, flour and soya } \\
\text { sauce }\end{array}$ & $\begin{array}{l}\text { Phospholipase D and } \\
\text { choline oxidase }\end{array}$ & Electrochemical & Mello and Kubota, 2002 \\
\hline
\end{tabular}

In the area of food safety, enzymatic biosensors allow for identifying the presence of highly toxic organic contaminants and the presence of anti-nutritional elements that affect the food chain, either accidently or by intention. This early detection protects the environment from contaminants and consumers from chronic illnesses and allergies.

Equally, enzymatic biosensors are being used in the food industry to determine the freshness of products given that it is possible to detect enzymes and compounds of aroma and flavor that originate from the senescence stage of products.

Biosensors have proven to be especially useful in the control of fermentative processes in follow-up of the consumption of the substrate by microorganisms, control of acidity and assessing the thermal profile.
While the use of biosensors in the food industry is on a mass scale, there are still obstacles to be overcome, such as the high cost of purifying the enzymes that are used as detecting elements, the low specificity and low response time that are obtained when complete cells or tissue are used, the lack of reliable responses low concentrations, interference reactions, the need to calibrate the devices and the stability of the enzymes. This last factor is the most limiting for the lifetime of enzymatic biosensors. If these limiting factors can be overcome, it will be possible to develop enzymatic biosensors that are more rapid, versatile, reliable, long lasting and cost-effective. 
Cuadro 4. Biosensor used in the evaluation of freshness and self life.

\begin{tabular}{lllll}
\hline Analyte & Matrix & \multicolumn{1}{c}{$\begin{array}{c}\text { Recognition } \\
\text { enzyme }\end{array}$} & $\begin{array}{c}\text { Transduction } \\
\text { system }\end{array}$ & References \\
\hline Polyphenols & Olive oil & Evaluation of spoilage & \\
$\begin{array}{c}\text { Short chain } \\
\text { fatty acid }\end{array}$ & Milk and derivatives & Lipase & Amperometric & $\begin{array}{l}\text { Campanella et al., 1993; } \\
\text { Kulys and Vidziunaite, 2003 } \\
\text { Mello and Kubota, 2002 }\end{array}$ \\
\hline
\end{tabular}

\section{Freshness index}

\begin{tabular}{|c|c|c|c|c|}
\hline $\begin{array}{l}\text { Ornithine } \\
\text { and amines }\end{array}$ & Shrimps & $\begin{array}{l}\text { Ornititne carbamoyl } \\
\text { transferase, nucleoside } \\
\text { phosphorylase and } \\
\text { xanthine oxidase }\end{array}$ & Amperometric & Mello and Kubota, 2002 \\
\hline
\end{tabular}

\begin{tabular}{|c|c|c|c|c|}
\hline Amines & Fish, lobster & $\begin{array}{l}\text { Diamine oxidase, } \\
\text { Ornithine carbamoyl } \\
\text { transferase, nucleoside } \\
\text { phosphorylase }\end{array}$ & Amperometric & $\begin{array}{l}\text { Park et al., 2000; Mello and } \\
\text { Kubota, } 2002\end{array}$ \\
\hline $\begin{array}{l}\text { Biogenic } \\
\text { amines }\end{array}$ & Fish & $\begin{array}{l}\text { Amine oxidase and } \\
\text { peroxidase }\end{array}$ & Amperometric & Tombelli and Mascini, 1998 \\
\hline $\begin{array}{l}\text { Hypoxan } \\
\text { thine }\end{array}$ & Fish & Xanthine oxidase & Amperometric & Hu et al., 2000 \\
\hline Lactic acid & Meat & $\begin{array}{l}\text { Xanthine oxidase, } \\
\text { diamine oxidase } \\
\text { Polymide oxidase }\end{array}$ & Amperometric & Mello and Kubota, 2002 \\
\hline
\end{tabular}

\section{Evaluation of maturity}

\begin{tabular}{|c|c|c|c|c|}
\hline Glucose & Fruit & Glucose oxidase & Electrochemical & Ramanathan et al., 2001 \\
\hline Sucrose & Fruit & $\begin{array}{l}\text { Invertase, mutarotase and } \\
\text { glucose oxidase }\end{array}$ & Electrochemical & Mello and Kubota, 2002 \\
\hline Isocitrate & Fruit & Isocitrate dehydrogenase & Potentiometric & Mello \& Kubota, 2002 \\
\hline
\end{tabular}

\section{RESUMEN}

Uso de biosensores enzimáticos como indicadores de calidad: Una sinopsis del presente y futuro en la industria alimentaria. Los biosensores constituyen una importante alternativa en la industria de alimentos para garantizar la calidad e inocuidad de los productos y controlar los procesos con métodos eficaces, rápidos y económicos; su tecnología está basada en un elemento de reconocimiento biológico específico en combinación con un transductor para el procesamiento de la señal. El uso de técnicas de biosensores enzimáticos en procesamiento de alimentos, control de calidad y de procesos "on line", es prometedor frente a las técnicas analíticas convencionales, ya que ofrecen grandes ventajas debido a su tamaño, costo, especificidad, respuesta rápida, precisión y sensibilidad. En este artículo se revisa el desarrollo y uso de algunos biosensores enzimáticos en la industria alimentaria, se describen las áreas de aplicación más importantes y se analiza su situación actual y posibilidades futuras. En conclusión, los biosensores enzimáticos son una herramienta de gran aplicabilidad en el desarrollo de sistemas de calidad como el análisis de riesgos y puntos críticos de control, y que la masificación de su uso en la industria alimentaria se ve aún limitada principalmente por el tiempo de vida útil de los biosensores, para lo cual se propone el uso de enzimas termofílicas.

Palabras clave: biosensores, enzimas, análisis en alimentos, seguridad, calidad, control de procesos. 


\section{LITERATURE CITED}

Akyilmaz, E., and E. Dinckaya. 2000. A mushroom (Agaricus bisporus) tissue homogenate based alcohol oxidase electrode for alcohol determination in serum. Talanta 53:505-509.

Ángeles A., y M. Cañizares. 2004. Desarrollo de un sistema sensor para la cuantificación de glucosa en jugos de frutas. Rev. Soc. Quím. Méx. 8:106-110.

Arroyo, M.1998. Inmovilización de enzimas. Fundamentos, métodos y aplicaciones. Ars Pharmaceutica 39:23-39.

Bachmann, T.T., B. Leca, F. Vilatte, J.L. Marty, D. Fournier, and R.D. Schmid. 2000. Improved multianalyte detection of organophosphates and carbamates with disposable multielectrode biosensors using recombinant mutants of Drosophila acetylcholinesterase and artificial neural networks. Biosens. Bioelectron. 15:193-201.

Bassi, A.S., E. Lee, and J.X. Zhu. 1998. Carbon paste mediated, amperometric, thin film biosensors for fructose monitoring in honey. Food Research Internacional 31:119-127.

Campanella, L., T. Beone, M.P. Sammartino, and M. Tomassetti. 1993. Analysis of L-dopa in pharmaceutical preparations and of total phenols content in urine by means of an enzyme-amperometric sensor. J. Pharm. Biomed. Anal. 11:1099-1104.

Campás, M., M. Mir, C. O’Sullivan, y I. Katakis. 2002. Biosensores al servicio de la industria alimentaria. In $2^{\circ}$ Congreso Español de Ingeniería de Alimentos, Lleida, España.

Centonze, D., C.G. Zambonin, and F. Palmisano. 1997. Determination of glucose in nonalcoholic beverages by a biosensor coupled with microdialysis fiber samplers. Journal of AOAC International 80:829-833.

Cosnier, S., C. Gondran, J.C. Watelet, W. De Giovani, R.P.M. Furriel, and F.A. Leone. 1998. A bienzyme electrode (alkaline phosphatase-polyphenol oxidase) for the amperometric determination of phosphate. Anal. Chem. 70:3952-3956.

Davis, J., D. Huw Vaughan, and M.F. Cardosi. 1995. Elements of biosensors construction. Enzyme Microb. Technol. 17:1030-1035.

Deng, Q., and S. Dong. 1996. Amperometric biosensor for tyrosinase inhibitors in a pure organic phase. Analyst 121:1979-1982.

D’Orazio, P. 2003. Biosensors in clinical chemistry. Clin. Chim. Acta 334:41-69.

D’Souza, S.F. 2001. Microbial biosensors. Biosen. Bioelectron. 16:337-353.

Eggins, B.R., C. Hickey, S.A. Toft, and D.M. Zhou. 1997. Determination of flavonols in beers with tissue biosensors. Anal. Chim. Acta 347:281-288.
Ferreira, S., M.B. De Souza, J.O. Trierweiler, O. Broxtermann, R.O.M. Folly, and B. Hitzmann. 2003. Aspects concerning the use of biosensors for process control: experimental and simulation investigations. Comput. Chem. Eng. 27:1165-1173.

Fitzpatrick, J., L. Fanning, S. Hearty, P. Leonard, B.M. Manning, J.G. Quinn, and R. O’Kennedy. 2000. Applications and recent developments in the use of antibodies for analysis. Anal. Lett. 33:2563-2609.

FSA. 2004. An investigation of the use of terms such as natural, fresh etc. in food labeling. Survey report of the February 11, 2004, Food Labelling and Standards Division, Food Standards Agency. (FSA), UK.

Gajovic, N., G. Binyamin, A. Warsinke, F.W. Scheller, and A. Heller. 2000. Operation of a miniature redox hydrogel-based pyruvate sensor in undiluted deoxygenated calf serum. Anal. Chem. 72:29632968.

Gibson, T.D. 1999. Biosensors: the stability problem. Analusis 27:630-638.

Glazier, S.A., M.A. Arnold, and J.P. Glazier. 1988. Evaluation of an overdetermined system based on multiple ion-selective electrodes of the same type. Talanta 35:215-219.

Hall, R.H. 2002. Biosensor technologies for detecting microbiological foodborne hazards. Microbes and Infect. 4:425-432.

Hedenmo, M., A. Narváez, E. Domínguez, and I. Katakis. 1997. Improved mediated tyrosinase amperometric enzyme electrodes. J. Electroanal. Chem. 425:1-11.

Hu, S., C. Xu, J. Luo, J. Luo, and D. Cui. 2000. Biosensor for detection of hypoxanthine based on xanthine oxidase immobilized on chemically modified carbon paste electrode. Anal. Chim. Acta 412:55-61.

Katrlık, J., J. Svorc, M. Stred'ansky, and S. Miertus. 1998. Composite alcohol biosensors based on solid binding matrix. Biosens. Bioelectron. 13:183-191.

Kelly, S.C., P.J. O’Connell, C.K. O’Sullivan, and G.G. Guilbault. 2000. Development of an interferent free amperometric biosensor for determination of L-lysine in food. Anal. Chim. Acta 412:111-119.

Killard, A.J., and M.R. Smyth. 2000. Separation-free electrochemical immunosensor strategies. Anal. Lett. 33:1451-1465.

Kotsira, V.P., and Y.D. Clonis. 1998. Colorimetric assay for lecithin using two co-immobilized enzymes and an indicator dye conjugate. J. Agric. Food Chem. 46:3389-3394.

Krajewska, B. 2004. Application of chitin- and chitosanbased materials for enzyme immobilizations: a review. J. Biotechnol. 35:126-139. 
Kwong, A.W.K., B. Gründig, J. Hu, and R. Renneberg. 2000. Comparative study of hydrogel-immobilized L-glutamate oxidases for a novel thick-film biosensor and its application in food samples. Biotechnol. Lett. 22:267-272.

Kulys, J., and R. Vidziunaite. 2003. Amperometric biosensors based on recombinant laccases for phenols determination. Biosen. and Bioelectron. 18:319-325.

Laschi, S., M. Fránek, and M. Mascini. 2000. Screenprinted electrochemical immunosensors for PCB detection. Electroanalysis 12:1293-1298.

Li, B., Z. Zhang, and Y. Jin. 2002. Plant tissuebased chemiluminescence flow biosensor for determination of unbound dopamine in rabbit blood with on-line microdialysis sampling. Biosens. and Bioelectron.17:585-589.

Luong, J.H.T, C.A. Groom, and K.B. Male. 1991. The potential role of biosensors in the food and drink industries. Biosens. and Bioelectron. 6:547-554.

Luong, J.H.T., K.B. Male, and J.D. Glennon. 2008. Biosensor technology: technology push versus market pull. Biotechnol. Adv. 26:492-500.

Marconi, E., G. Panfili, M.C. Messia, R. Cubadda, D. Compagnone, and G. Palleschi. 1996. Fast analysis of lysine in food using protein microwave hydrolysis and an electrochemical biosensor. Anal. Lett. 29:1125-1137.

Matsumoto, K., W. Asada, and R. Murai. 1998. Simultaneous biosensing of inosine monophosphate and glutamate by use of immobilized enzyme reactors. Anal. Chim. Acta 358:127-136.

Mei, Y., L. Ran, X. Ying, Z. Yuan, and S. Xin. 2007. A sequential injection analysis/chemiluminescent plant tissue-based biosensor system for the determination of diamine. Biosens. Bioelectron. 22:871-876.

Mello, L.D., and L.T. Kubota. 2002. Review of the use of biosensors as analytical tools in the food and drink industries. Food Chem. 77:237-256.

Miertus, S., J. Katrlík, A. Pizzariello, M. Stred’anský, J. Svitel, and J. Svorc. 1998. Amperometric biosensors based on solid binding matrices applied in food quality monitoring. Biosens. Bioelectron. 13:911-923.

Milardovic, S., Z. Grabaric, and B.S. Grabaric. 2000. Sensitive amperometric oxalate biosensor for food analysis. Food Technol. Biotechnol. 38:203-210.

Moore, E., M. Pravda, and G.G. Guilbault. 2003. Development of a biosensor for the quantitative detection of 2,4,6-trichloroanisole using screen printed electrodes. Anal. Chim. Acta 484:15-24.

Morales, M.D., S. Morante, A. Escarpa, M.C. González, A.J. Reviejo, and J.M. Pingarrón. 2002. Design of a composite amperometric enzyme electrode for the control of the benzoic acid content in food. Talanta 57:1189-1198.
Moretto, L.M., P. Ugo, M. Zanata, P. Guerriero, and C.R. Martin. 1998. Nitrate biosensor based on the ultrathinfilm composite membrane concept. Anal. Chem. 70:2163-2166.

Niculescu, M., R. Mieliauskiene, V. Laurinavicius, and E. Csöregi. 2003. Simultaneous detection of ethanol, glucose and glycerol in wines using pyrroloquinoline quinone dependent dehydrogenases based biosensors. Food Chem. 82:481-489.

Nunes, G.S., P. Skladal, H. Yamanaka, and D. Barcelo. 1998. Determination of carbamate residues in crop samples by cholinesterase-based biosensors and chromatographic techniques. Anal. Chim. Acta 362:59-68.

Odaci, D., S. Timur, and A. Telefoncu. 2004. Carboxyl esterase-alcohol oxidase based biosensor for the aspartame determination. Food Chem. 84:493-496.

Ohashi, E., and I. Karube. 1993. Sensors for the food industry. Food Control 4:183-188.

Olschewski, H., A. Erlenkötter, C. Zaborosch, and G.C. Chemnitius. 2000. Screen-printed enzyme sensors for l-lysine determination. Enzyme Microb. Technol. 26:537-543.

Palmisano, F., R. Rizzi, D. Centonze, and P.G. Zambonin. 2000. Simultaneous monitoring of glucose and lactate by an interference and cross-talk free dual electrode amperometric biosensor based on electropolymerized thin films. Biosens. Bioelectron. 15:531-539.

Panfili, G., P. Manzi, D. Compagnone, L. Scarciglia, and G. Palleschi. 2000. Rapid assay of choline in foods using a microwave hydrolysis and a choline biosensor. J. Agr. Food Chem. 48:3403-3407.

Parellada, J., A. Narváez, M.A. López, E. Domínguez, J.J. Fernández, V. Pavlov, and I. Katakis. 1998. Amperometric immunosensors and enzyme electrodes for environmental applications. Anal. Chim. Acta 362:47-57.

Park, I.-S., Y.-J. Cho, and N. Kim. 2000. Characterization and meat freshness application of a serial threeenzyme reactor system measuring ATP-degradative compounds. Anal. Chim. Acta 404:75-81.

Patel, P.D. 2002. (Bio)sensors for measurement of analytes implicated in food safety: a review. Trends Anal. Chem. 21:96-115.

Pérez Pita, M.T., A.J. Reviejo, F.J. Manuel de Villena, and J.M. Pingarrón. 1997. Amperometric selective biosensing of dimethyl- and diethyldithiocarbamates based on inhibition processes in a medium of reversed micelles. Anal. Chim. Acta 340:89-97.

Prodromidis, M.I., S.M. Tzouwara-Karayanni, M.I. Karayannis, and P.M. Vadgama. 1997. Bioelectrochemical determination of citric acid in real samples using a fully automated flow injection manifold. Analyst 122:1101-1106. 
Ramanathan, K., B.R. Jönsson, and B. Danielsson. 2001. Sol-gel based thermal biosensor for glucose. Anal. Chim. Acta 427:1-10.

Rasooly, A. 2001. Surface plasmon resonance analysis of Staphylococcal enterotoxin B in food. Food Protec. 64:37-43.

Rogers, K.R., and M. Mascini. 1998. Biosensors for field analytical monitoring. Field Anal. Chem. Technol. 2:317-331.

Saidman, S.B., M.J. Lobo-Castañón, A.J. MirandaOrdieres, and P. Tuñón-Blanco. 2000. Amperometric detection of D-sorbitol with $\mathrm{NAD}^{+}$-D-sorbitol dehydrogenasse modified carbon paste electrode. Anal. Chim. Acta 424: 45-50.

Sarkar, P., I.E. Tothill, S.J. Setford, and A.P.F. Turner. 1999. Screen-printed amperometric biosensors for the rapid measurement of L- and D-amino acids. Analyst 124:865-870.

Sekine, Y., and E.A.H. Hall. 1998. A lactulose sensor based on coupled enzyme reactions with a ring electrode fabricated from tetrathiafulvalen-tetracyanoquinodimetane. Biosens. Bioelectron. 13:995-1005.

Setti, L., A. Fraleoni-Morgera, I. Mencarelli, A. Filippini, B. Ballarin, and M. Di Biase. 2007. An HRP-based amperometric biosensor fabricated by thermal inkjet printing. Sensor Actuator B- Chem. 126:252-257.

Silber, A., C. Bräuchle, and N. Hampp. 1994. Dehydrogenase-based thick-film biosensors for lactate and malate. Sensor Actuator B- Chem. 18:235-239.

Smyth, A.B., P.C. Talasila, and A.C. Cameron. 1999. An ethanol biosensor can detect low-oxygen injury in modified atmosphere packages of fresh-cut produce. Postharvest Biol. Technol. 5:127-134

Tatsumi, H., H. Katano, and T. Ikeda. 2006. Kinetic analysis of enzymatic hydrolysis of crystalline cellulose by cellobiohydrolase using an amperometric biosensor. Anal. Biochem. 357:257-261.
Tingry, S., C. Innocent, S. Touil, A. Deratani, and P. Seta. 2006. Carbon paste biosensor for phenol detection of impregnated tissue: modification of selectivity by using $\beta$-cyclodextrin-containing PVA membrane. Mater. Sci. Eng. C 26:222-226.

Tombelli, S., and M. Mascini. 1998. Electrochemical biosensors for biogenic amines: A comparison between different approaches. Anal. Chim. Acta 358:277-284.

Tothill, I.E. 2001. Biosensors developments and potential applications in the agricultural diagnosis sector. Comp. Electron. Agr. 30:205-218.

Tsai, H.C., R.A. Doong, H.C. Chiang and K.T. Chen. 2003. Sol-gel derived urease-based optical biosensor for the rapid determination of heavy metals. Anal. Chim. Acta 481:75-84.

Vadiuambal, R., and D.S. Jayas. 2007. Changes in quality of microwave-treated agricultural products: a review. Biosyst. Eng. 98:1-16.

Velasco-García, M.N., and T. Mottram. 2003. Biosensor technology addressing agricultural problems. Review paper. Biosyst. Eng. 84:1-12.

Volpe, G., and M. Mascini. 1996. Enzyme sensors for determination of fish freshness. Talanta 43:283-289

Wilson, G.S., and R. Gifford. 2005. Review biosensors for real-time in vivo measurements. Biosens. Bioelectron. 20:2388-2403.

Xavier, M.P., B. Vallejo, M.D. Marazuela, M.C. MorenoBondi, F. Baldini, and A. Falai. 2000. Fiber optic monitoring of carbamate pesticides using porous glass with covalently bound chlorophenol red. Biosens. Bioelectron. 14:895-905.

Zhang, Z., and R.P. Wilson. 1998. A modified enzymatic assay for quantifying choline in fish tissue and common feed ingredients. J. Agr. Food Chem. 46:3673-3676.

Zinedine, A., J.M. Soriano, J.C Molto, and J. Mañes. 2007. Review on the toxicity, occurrence, metabolism, detoxification, regulations and intake of zearalenone: an oestrogenic mycotoxin. Food Chem. Toxicol. 45:1-18. 